\title{
Seroprevalence and current infections of canine vector-borne diseases in Nicaragua
}

\author{
Andrea Springer ${ }^{1}$, Victor M. Montenegro ${ }^{2}$, Sabine Schicht ${ }^{1}$, Nikola Pantchev ${ }^{3}$ and Christina Strube ${ }^{1 *}$
}

\begin{abstract}
Background: Vector-borne diseases constitute a major problem for veterinary and public health, especially in tropical regions like Central America. Domestic dogs may be infected with several vector-borne pathogens of zoonotic relevance, which may also severely compromise canine health.

Methods: To assess the prevalence of canine vector-borne diseases in Nicaragua, 329 dogs from seven cities, which were presented to the veterinarian for various reasons, were included in this study. Dogs were examined clinically and diagnostic blood samples were taken for analysis of packed cell volume (PCV) and presence of microfilariae as well as antigen of Dirofilaria immitis and antibodies to Ehrlichia spp., Anaplasma spp. and Borrelia burgdorferi (sensu lato) by use of a commercially available rapid ELISA. To detect current infections, specific PCRs for the detection of E. canis, A. platys and A. phagocytophilum were carried out on blood samples of the respective seropositive dogs. Microfilaremic blood samples, as well as D. immitis antigen positive samples were further subjected to PCR and subsequent sequencing for filarial species identification.
\end{abstract}

Results: Antibodies against Ehrlichia spp. were present in 62.9\% of dogs, while Anaplasma spp. seroprevalence was 28. $6 \%$. Antibodies against species of both genera were detected in $24.9 \%$ of dogs. Borrelia burgdorferi (s.l.) antibodies were not detected. Dirofilaria immitis antigen was present in six animals (1.8\%), two of which also showed D. immitis microfilariae in buffy coat. In addition to D. immitis, Acanthocheilonema reconditum was identified by PCR and sequencing in two of four additional microfilaremic blood samples, which were tested negative for $D$. immitis antigen. Current E. canis infections as defined by DNA detection were present in $58.5 \%$ of Ehrlichia-seropositive dogs, while $5.3 \%$ of Anaplasma-seropositive dogs were PCR-positive for A. platys, 2.2\% for A. phagocytophilum and 16.0\% for both Anaplasma species. Current E. canis infection had a statistically significant negative impact on PCV, whereas no relationship between infection status and clinical signs of disease could be observed.

Conclusions: These results indicate that canine vector-borne diseases are widespread in Nicaragua and that dogs may constitute a reservoir for human infection with E. canis, A. phagocytophilum and D. immitis. Thus, the use of repellents or acaricides to protect dogs from vector-borne diseases is strongly recommended.

Keywords: Vector-borne diseases, Tick-borne diseases, Ticks, Zoonoses, Rickettsia spp., Ehrlichia spp., Anaplasma spp., Central America

\section{Background}

Vector-borne pathogens constitute an important problem for veterinary and public health, especially in tropical regions where the climate is ideal for vectors such as ticks and mosquitoes [1]. Domestic dogs may be affected by several vector-borne diseases, including leishmaniosis, babesiosis, ehrlichiosis, anaplasmosis and

\footnotetext{
* Correspondence: christina.strube@tiho-hannover.de

${ }^{1}$ Institute for Parasitology, Centre for Infection Medicine, University of

Veterinary Medicine Hannover, Buenteweg 17, 30559 Hannover, Germany

Full list of author information is available at the end of the article
}

canine heartworm disease, which may severely compromise canine health. Clinical signs are often unspecific, including fever, lymphadenopathy or weight loss with haematologic abnormalities including anaemia and thrombocytopenia [2]. Co-infections are common in endemic areas and may alter and/or potentiate clinical signs, complicating diagnosis and treatment [3]. However, dogs may also be infected without showing any signs of disease or haematologic abnormalities [4].

(c) The Author(s). 2018 Open Access This article is distributed under the terms of the Creative Commons Attribution 4.0 International License (http://creativecommons.org/licenses/by/4.0/), which permits unrestricted use, distribution, and reproduction in any medium, provided you give appropriate credit to the original author(s) and the source, provide a link to the Creative Commons license, and indicate if changes were made. The Creative Commons Public Domain Dedication waiver (http://creativecommons.org/publicdomain/zero/1.0/) applies to the data made available in this article, unless otherwise stated. 
Many canine vector-borne diseases are of major zoonotic concern, including Lyme borreliosis, granulocytic anaplasmosis, ehrlichiosis and spotted-fever rickettsioses. Dogs may act as reservoirs and sentinels for human infection with these pathogens $[4,5]$. In consequence, surveillance of canine vector-borne diseases may reveal infection risks for humans and potential disease emergence foci [2, 6]. For example, Borrelia burgdorferi seroprevalence in dogs in the USA was higher in areas with a large number of human Lyme borreliosis cases [7]. Similarly, dogs living in areas associated with human rickettsiosis outbreaks in Costa Rica showed a higher Rickettsia seroprevalence than dogs elsewhere [8].

For Central America, prevalence data on canine vector-borne diseases are relatively scarce. In recent years, surveys have been published for Costa Rica [9-11] and Panama [12, 13], demonstrating a high prevalence of Ehrlichia spp., followed by Anaplasma spp. infections. Furthermore, Dirofilaria immitis infections were detected in Costa Rica, with a high regional prevalence in provinces along the Pacific coast $[9,11]$. Comparable prevalence rates for Ehrlichia spp., Anaplasma spp. and D. immitis were also detected in Mexico [14]. Regarding Nicaragua, which borders Costa Rica to the north, comparable large-scale studies are lacking. Only a small-scale study ( $n=39$ dogs) has been conducted so far [15].

Therefore, seroprevalence of antibodies to Ehrlichia spp., Anaplasma spp. and B. burgdorferi (sensu lato) as well as antigen of $D$. immitis in dogs from seven different localities in Nicaragua was assessed in this study. Seropositive dogs were further tested by pathogen-specific PCRs for current infections, and relationships with clinical signs were explored.

\section{Methods}

\section{Clinical examination and sampling of dogs}

From September to October 2013, 329 dogs which were presented at veterinary clinics for various reasons were clinically examined and sampled in seven different cities in western Nicaragua. Four of these cities are located in the Pacific lowlands (Chinandega, León, Managua and Masaya), one at the Pacific coast (Corinto) and two in the central highlands (Jinotega and Juigalpa, Fig. 1). Per city, 31-83 dogs were sampled (Table 1). Most dogs were presented by their owners, whereas only in Managua, 12 dogs from an animal shelter were included in the study. Inclusion criteria for the dogs were the following: more than six months of age; not treated with ivermectin during the last six months nor with doxycycline during the last 12 months; and consent of the owner to use surplus samples for further examinations. Sex, age and breed of each dog were noted and a clinical examination was carried out. Diagnostic blood samples were taken from the cephalic or jugular vein and collected into serum and EDTA tubes. Packed cell volume (PCV) was determined by glass capillary centrifugation of EDTA blood. Remaining EDTA blood and serum was stored at $-20{ }^{\circ} \mathrm{C}$ for further analyses.

\section{Screening of blood samples for vector-borne pathogens}

Canine serum samples were tested for antibodies against Anaplasma spp., Ehrlichia spp. and B. burgdorferis (s.l.), as well as antigen of $D$. immitis, by use of a commercially available rapid ELISA (SNAP ${ }^{\circ} 4 \mathrm{Dx}^{\circ}$ Plus, IDEXX Laboratories Inc., Westbrook, ME, USA). According to Stillman et al. [16] the sensitivity and specificity of the test system are 93.2 and $99.2 \%$ for A. phagocytophilum, 89.2 and $99.2 \%$ for A. platys, 96.7 and $98.8 \%$ for B. burgdorferi (s.l.), 97.8 and $92.3 \%$ for E. canis, and 98.9 and 99.3\% for D. immitis. Furthermore, a cross-reactivity of $E$. canis antigens with anti-E. chaffeensis antibodies was shown. Due to documented cross-reactivity between $A$. phagocytophilum and A. platys [17], as well as the reactivity to E. canis, E. chaffeensis and E. ewingii [16, 18], we refer to Anaplasma spp. and Ehrlichia spp. as results in the present study. Additionally, buffy coat of all dogs was investigated microscopically for presence of microfilariae. This technique has a comparable sensitivity to the Knott's test, if at least 25 microfilariae are present per $\mathrm{ml}$ of blood sample [19].

To determine which Anaplasma- and Ehrlichia-seropositive dogs were currently infected (as defined by DNA detection) with $E$. canis, A. phagocytophilum and A. platys, respectively, species-specific PCRs were carried out. DNA was isolated from blood samples using the Nucleospin 8 Blood Kit (Macherey-Nagel GmbH \& Co. KG, Düren, Germany) according to the manufacturer's instructions.

Samples were tested for A. phagocytophilum by employing a nested PCR targeting a $546 \mathrm{bp}$ fragment of the $16 \mathrm{~S}$ rRNA gene. Primers used were ge3a and ge10r in a first and ge9f and ge 2 in a second PCR round [20]. In each round, the $12.5 \mu \mathrm{l}$ reaction volume contained $6.25 \mu \mathrm{l}$ DreamTaq ${ }^{\circ}$ PCR Mastermix (Thermo Fisher Scientific Inc., Waltham, MA, USA), $0.5 \mu$ l of each primer (10 $\mu \mathrm{M}$ each), $4.25 \mu \mathrm{l}$ deionized water and $1 \mu \mathrm{l}$ template DNA. In the second round, template DNA was represented by the PCR product of the first round. The thermoprofile was the same for both rounds and consisted of an initial denaturation step at $95^{\circ} \mathrm{C}$ for $2 \mathrm{~min}$, followed by 40 cycles at $95{ }^{\circ} \mathrm{C}$ for $30 \mathrm{~s}, 55^{\circ} \mathrm{C}$ for $30 \mathrm{~s}$ and $72{ }^{\circ} \mathrm{C}$ for $1 \mathrm{~min}$, and a final elongation step at $72{ }^{\circ} \mathrm{C}$ for $5 \mathrm{~min}$.

To detect A. platys, a nested PCR targeting a 678 bp fragment of the $16 S$ rRNA gene was carried out using primer sets $8 \mathrm{~F}$ and 1448R for a first and EHR16SR and PLATYS for a second PCR round [21]. Oligonucleotide concentration and reaction set-up were as described above except that $2.5 \mu \mathrm{l}$ template DNA was used and 

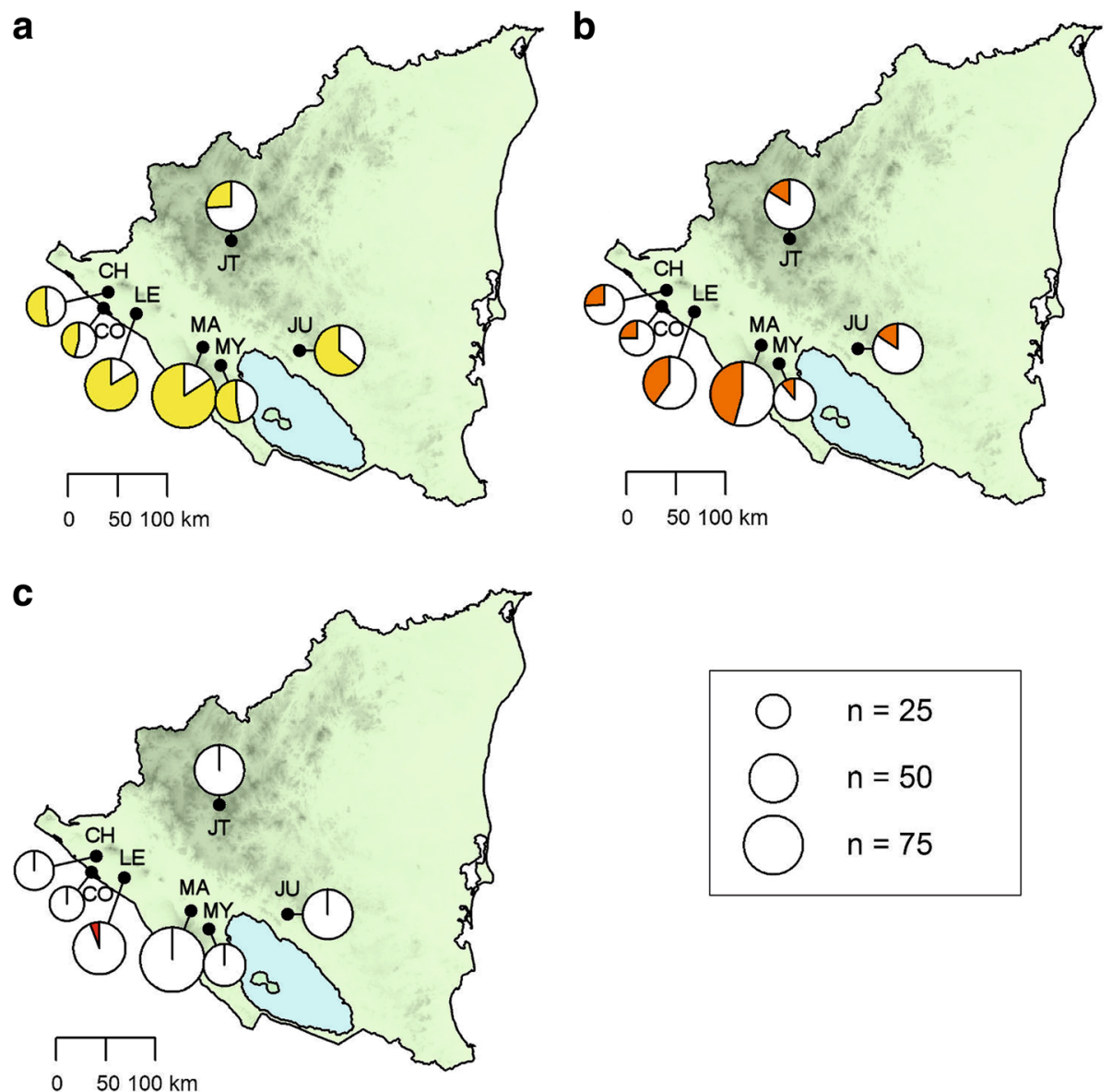

Fig. 1 Seroprevalence of antibodies against Ehrlichia spp. (a) and Anaplasma spp. (b) as well as antigen of Dirofilaria immitis (c) in dogs tested by rapid ELISA in different cities of Nicaragua from September to December 2013. The size of pie charts corresponds to the number of dogs sampled at each site. Abbreviations: CH, Chinandega; CO, Corinto; JU, Juigalpa; JT, Jinotega; LE, Léon; MA, Managua; MY, Masaya

the amount of water was adjusted accordingly. The thermoprofile of the first round consisted of an initial denaturation at $95{ }^{\circ} \mathrm{C}$ for $2 \mathrm{~min}$, followed by 40 cycles at $95{ }^{\circ} \mathrm{C}$ for $1 \mathrm{~min}, 45{ }^{\circ} \mathrm{C}$ for $1 \mathrm{~min}$ and $72{ }^{\circ} \mathrm{C}$ for $2 \mathrm{~min}$, and final extension at $72{ }^{\circ} \mathrm{C}$ for $5 \mathrm{~min}$. The thermoprofile of the second round consisted of an initial denaturation at $95{ }^{\circ} \mathrm{C}$ for $1 \mathrm{~min}$, followed by 40 cycles at $95{ }^{\circ} \mathrm{C}$ for $30 \mathrm{~s}, 55^{\circ} \mathrm{C}$ for $30 \mathrm{~s}$ and $72{ }^{\circ} \mathrm{C}$ for $30 \mathrm{~s}$, and a final extension at $72{ }^{\circ} \mathrm{C}$ for $5 \mathrm{~min}$.

For detection of E. canis, a 389 bp fragment of the $16 S$ rRNA gene was targeted by nested PCR using primer pairs ECC and ECB in a first and ECAN5 and HE3 in a second PCR round $[22,23]$. In the first round, the $25 \mu \mathrm{l}$ reaction volume contained $12.5 \mu$ l DreamTaq ${ }^{\circ}$ PCR

Table 1 Number of dogs sampled, seroprevalence of Anaplasma spp. and Ehrlichia spp. and prevalence of Dirofilaria immitis antigen as determined by rapid ELISA, at the different sampling locations in Nicaragua

\begin{tabular}{llllllll}
\hline City & $\begin{array}{l}\text { Geographical } \\
\text { region }\end{array}$ & $\begin{array}{l}\text { No. of dogs } \\
\text { sampled }\end{array}$ & $\begin{array}{l}\text { Seroprevalence } \\
\text { of Anaplasma spp. }\end{array}$ & $\begin{array}{l}\text { Seroprevalence } \\
\text { of Ehrlichia spp. }\end{array}$ & $\begin{array}{l}\text { Seroprevalence of } \\
\text { Borrelia burgdorferi (s.l.) }\end{array}$ & $\begin{array}{l}\text { Prevalence } \\
\text { of D. immitis }\end{array}$ & $\begin{array}{l}\text { Prevalence of } \\
\text { tick infestation }\end{array}$ \\
\hline Corinto & Pacific coast & 24 & $6 / 24(25.0 \%)$ & $11 / 24(45.8 \%)$ & 0 & 0 & $5 / 24(20.8 \%)$ \\
León & Pacific lowlands & 55 & $22 / 55(40.0 \%)$ & $46 / 55(83.6 \%)$ & 0 & $6 / 55(10.9 \%)$ & $40 / 55(72.7 \%)$ \\
Chinandega & Pacific lowlands & 31 & $8 / 31(25.8 \%)$ & $16 / 31(51.6 \%)$ & 0 & 0 & $14 / 31(45.2 \%)$ \\
Managua & Pacific lowlands & 83 & $38 / 83(45.8 \%)$ & $70 / 83(84.3 \%)$ & 0 & 0 & $36 / 83(43.4 \%)$ \\
Masaya & Pacific lowlands & 36 & $4 / 36(11.1 \%)$ & $19 / 36(52.8 \%)$ & 0 & 0 & $14 / 36(38.9 \%)$ \\
Jinotega & Central highlands & 50 & $8 / 50(16.0 \%)$ & $13 / 50(26.0 \%)$ & 0 & 0 & $23 / 50(46.0 \%)$ \\
Juigalpa & Central highlands & 50 & $8 / 50(16.0 \%)$ & $32 / 50(64.0 \%)$ & 0 & 0 & $27 / 50(54.0 \%)$ \\
Total & & 329 & $94 / 329(28.6 \%)$ & $207 / 329(62.9 \%)$ & $0 / 329(0.0 \%)$ & $6 / 329(1.8 \%)$ & $159 / 329(48.3 \%)$ \\
\hline
\end{tabular}


Mastermix, $0.5 \mu \mathrm{l}$ of ECC $(0.4 \mu \mathrm{M}), 0.5 \mu \mathrm{l}$ of ECB $(10 \mu \mathrm{M})$, $9.5 \mu \mathrm{l}$ deionized water and $2 \mu \mathrm{l}$ template DNA, while in the second round, $0.5 \mu \mathrm{l}$ each of primers ECAN5 $(0.4 \mu \mathrm{M})$ and HE3 $(10 \mu \mathrm{M})$ as well as $2.5 \mu \mathrm{l}$ of the PCR-product of the first round were used, and the amount of water was adjusted to $9 \mu$ l. The thermoprofile consisted of an initial denaturation at $95{ }^{\circ} \mathrm{C}$ for $2 \mathrm{~min}$, followed by 40 cycles at $95^{\circ} \mathrm{C}$ for $1 \mathrm{~min}, 60^{\circ} \mathrm{C}$ for $1 \mathrm{~min}$ and $72{ }^{\circ} \mathrm{C}$ for $1 \mathrm{~min}$, and a final extension at $72{ }^{\circ} \mathrm{C}$ for $5 \mathrm{~min}$ in the first round. In the second round, a thermoprofile of initial denaturation at $95^{\circ} \mathrm{C}$ for $1 \mathrm{~min}$, followed by 40 cycles at $95^{\circ} \mathrm{C}$ for $30 \mathrm{~s}$, $55^{\circ} \mathrm{C}$ for $30 \mathrm{~s}$ and $72{ }^{\circ} \mathrm{C}$ for $30 \mathrm{~s}$, and a final extension at $72^{\circ} \mathrm{C}$ for 5 min was used. In all PCR set-ups, positive and no template controls were included.

Samples which were positive for D. immitis antigen in the ELISA or contained microfilariae in buffy coat were subjected to a PCR targeting the internal transcribed spacer (ITS) 1-5.8S rDNA-ITS2 complex by use of primers $\mathrm{NC} 2$ and NC5 [24]. The $50 \mu \mathrm{l}$ reaction volume contained $1 \mu \mathrm{l} \mathrm{Taq}$ polymerase (5 PRIME GmbH, Hilden, Germany), $5 \mu \mathrm{l} 10 \times$ buffer, $2 \mu \mathrm{l}$ of each primer $(10 \mu \mathrm{M}$ each), $1 \mu \mathrm{l}$ deoxynucleotide triphosphates ( $10 \mathrm{mM}$ each), $37 \mu \mathrm{l}$ deionized water and $2 \mu \mathrm{l}$ template DNA. The thermoprofile consisted of an initial denaturation step at $95{ }^{\circ} \mathrm{C}$ for 3 min, 30 cycles at $95{ }^{\circ} \mathrm{C}$ for $30 \mathrm{~s}, 55^{\circ} \mathrm{C}$ for $30 \mathrm{~s}, 72{ }^{\circ} \mathrm{C}$ for $30 \mathrm{~s}$, followed by final elongation at $72{ }^{\circ} \mathrm{C}$ for $10 \mathrm{~min}$. After visualization on $1 \%$ agarose gels, bands of the expected size between 1000 and $1500 \mathrm{bp}$ were ligated into a $\mathrm{pCR}^{\mathrm{m}} 4-\mathrm{TOPO}^{\circ} \mathrm{TA}$ vector and cloned into One Shot Top10 chemically competent Escherichia coli $\left(\mathrm{TOPO}^{\circ} \mathrm{TA}\right.$ Cloning kit, Thermo Fisher Scientific GmbH, Dreieich, Germany). After plasmid extraction and purification (NucleoSpin Plasmid kit, Macherey-Nagel GmbH \& Co. KG, Düren, Germany), the insert was sequenced at the Seqlab Sequence Laboratories (Göttingen, Germany).

\section{Statistical analyses}

Statistical analyses were conducted in R v. 3.3.1 [25]. To investigate which factors influenced the probability of Anaplasma spp. and Ehrlichia spp. seropositivity in the rapid ELISA, generalized linear models (GLMs) with binomial error structure and logit-link were constructed $(\mathrm{R}$ function 'glm'). Animal age, sex, breed (dichotomized into "with breed"/"mongrel"), city of sampling and tick infestation at the time of examination were included as predictors. Furthermore, Anaplasma spp. infection was included as a predictor in the model for Ehrlichia spp., and vice-versa, to examine associations between seroprevalence for these pathogens. A third model was constructed to examine which factors influenced the likelihood of a positive result for one or more pathogens in the rapid ELISA in general. Full models were compared to null models containing only an intercept term in a likelihood ratio test ( $\mathrm{R}$ function 'anova', test $=$ 'chisq'). Model fit was assessed by Hosmer-Lemeshow-tests and inspection of Receiver Operating Characteristic (ROC) curves. Multiple comparisons (Tukey contrasts) between all levels of the factor "city" were performed using the function 'glht' (package multcomp [26]), with single-step $P$-value adjustment.

The influence of current infections with $A$. platys, $A$. phagocytophilum and E. canis (PCR results) on packed cell volume (PCV) was investigated using a linear mixed model (LMM, package lme4 [27]). Because animal age and sex may affect PCV in dogs [28], these variables were included as additional fixed factors, while the city of sampling was included as a random factor. Because $A$. platys and $A$. phagocytophilum infections were highly correlated, these factors were investigated in separate models. Full LMMs were compared to null models containing only the random factor in a likelihood ratio test ( $\mathrm{R}$ function 'anova', test $=$ 'chisq'). To validate LMM assumptions, normality and homogeneity of model residuals were investigated graphically.

The proportion of anorectic dogs was compared between E. canis-, A. platys- and A. phagocytophilum-infected and non-infected dogs using Fisher's exact test.

Since only six dogs were positive for $D$. immitis antigen, these infections were not considered in statistical analyses.

\section{Results \\ Clinical presentation of dogs}

During clinical examinations, tick infestation was noted on 159 of the $329 \operatorname{dogs}(48.3 \%)$, while flea and lice infestation were noted on $63(19.1 \%)$ and $9(2.7 \%)$ dogs, respectively. Pale mucous membranes were apparent in 129 dogs (39.2\%), while anorexia was reported for 19 dogs (5.8\%). Two dogs $(0.6 \%)$ showed apathy, fever, epistaxis and abdominal pain. Lymphadenopathy was noted in one dog $(0.3 \%)$. Other common clinical anomalies included nail overgrowth $(n=50 ; 15.2 \%)$, alopecia $(n=31 ; 9.4 \%)$, cough $(n=9 ; 2.7 \%)$ and eye discharge $(n=8 ; 2.4 \%)$.

\section{Seroprevalence of Rickettsiales and D. immitis}

Antibodies against Ehrlichia spp. were detected in 62.9\% (207/329) of dogs, while Anaplasma spp. seroprevalence was $28.6 \%$ (94/329). Antibodies against both Ehrlichia and Anaplasma spp. were detected in 82 animals (24.9\%), demonstrating exposure to species of both genera. Antibodies against $B$. burgdorferi (s.l.) were not detected. Regional seroprevalences are presented in Table 1 and Fig. 1.

Statistical analyses revealed a significant association of Ehrlichia and Anaplasma seropositivity; animals that were seropositive for Ehrlichia spp. had approximately 5 times higher odds of testing positive for Anaplasma antibodies as well, and vice versa (GLM, Table 2, models A and B). Additionally, a significant effect of age on the likelihood of Ehrlichia seropositivity was observed, as well as on the likelihood of a positive ELISA result in 


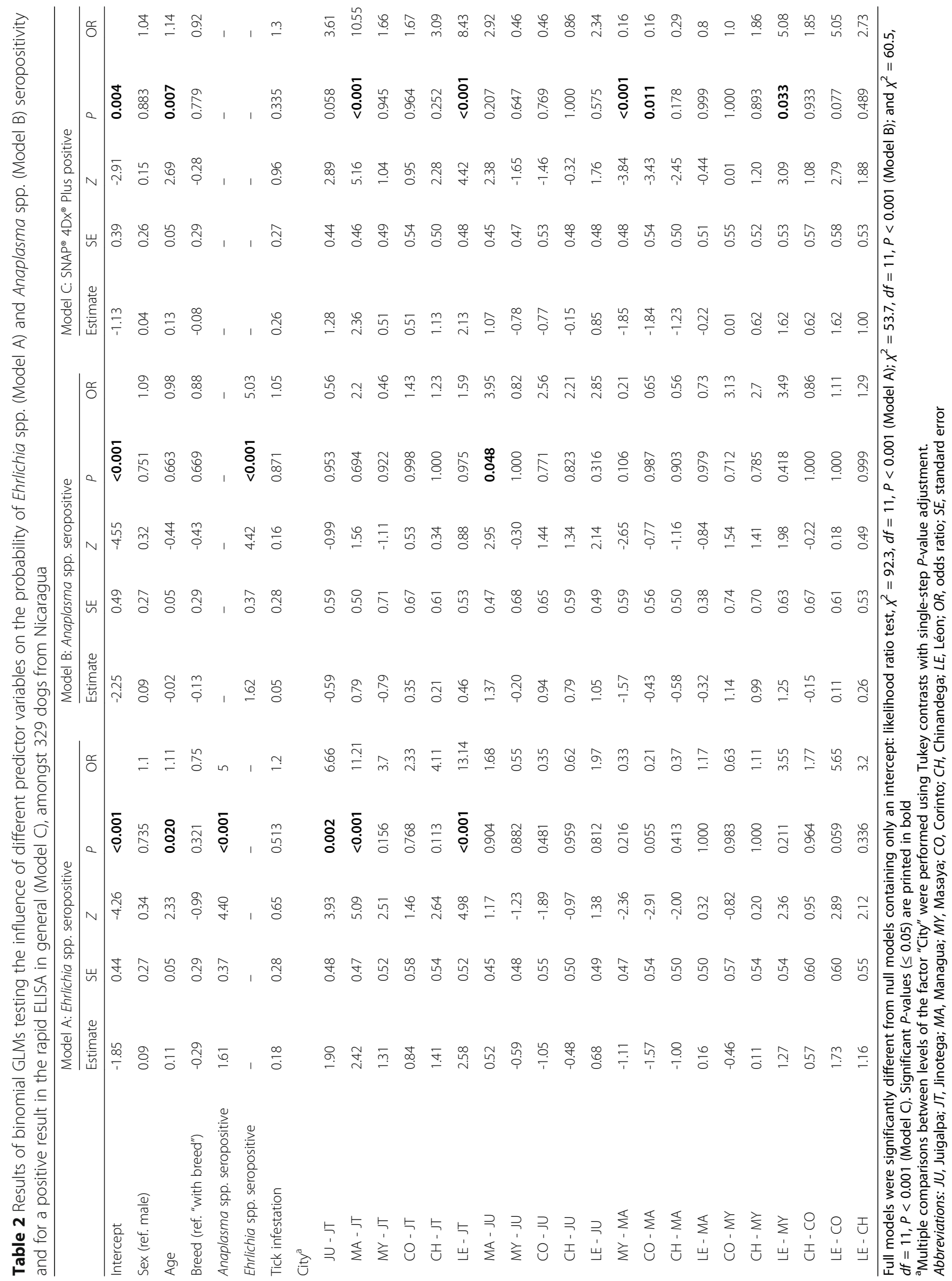


general (GLM, Table 2, model C), with increasing probability in older dogs. Furthermore, significant differences were observed between the different sampling locations. Particularly, the odds of testing seropositive for Ehrlichia spp. were significantly lower in the city of Jinotega compared to Managua, Juigalpa and Léon, whereas for Anaplasma spp., a significant difference was only observed between Managua and Juigalpa, with a higher risk in Managua. Considering the results for Anaplasma spp., Ehrlichia spp. and D. immitis together, the odds of testing seropositive for any of these pathogens were significantly higher in Managua and Léon compared to Jinotega, in Managua compared to Corinto and Masaya, and in Masaya compared to Léon (Table 2). In contrast, animal sex and breed (with breed/mongrel) had no influence on seropositivity. Furthermore, tick infestation at the time of presentation was also not associated with seropositivity.

\section{Current infections and their clinical impact}

In six dogs (1.8\%), which were all sampled at the city of Léon, $D$. immitis antigen was detected. In two of these samples, microfilariae were microscopically observed and confirmed as D. immitis by PCR and sequencing. Microfilariae were also observed in four additional samples, which did not test positive for $D$. immitis antigen. In two of these samples, Acanthocheilonema reconditum was identified by PCR and sequencing.

Current $E$. canis infection, as determined by amplification of the pathogen's DNA, was detected in 58.5\% (121/ 207) of Ehrlichia-seropositive dogs, while Anaplasma DNA was detected in $23.4 \%$ (22/94) of seropositive samples. Among the 94 animals tested for Anaplasma DNA, five dogs $(5.3 \%)$ were single-infected with $A$. platys, two dogs $(2.2 \%)$ were single-infected with $A$. phagocytophilum and 15 dogs (16.0\%) were co-infected with both species. Among the 85 animals tested by PCR for all three pathogens, four animals (4.7\%) were co-infected with $E$. canis and $A$. platys, one animal (1.2\%) with $E$. canis and $A$. phagocytophilum and eight animals (9.4\%) carried all three pathogens (Table 3).

In the clinical examination, $50.4 \%$ (61/121) of dogs with current E. canis infection, $75.0 \%(15 / 20)$ of dogs with current $A$. platys infections and $64.7 \%$ (11/17) of dogs with current $A$. phagocytophilum showed pale mucous membranes. However, 9 (45.0\%) and $6(35.3 \%)$ of these A. platysand $A$. phagocytophilum-infected dogs were co-infected with $E$. canis, respectively. Figure 2 shows the distribution of PCV in non-infected, mono-infected and co-infected

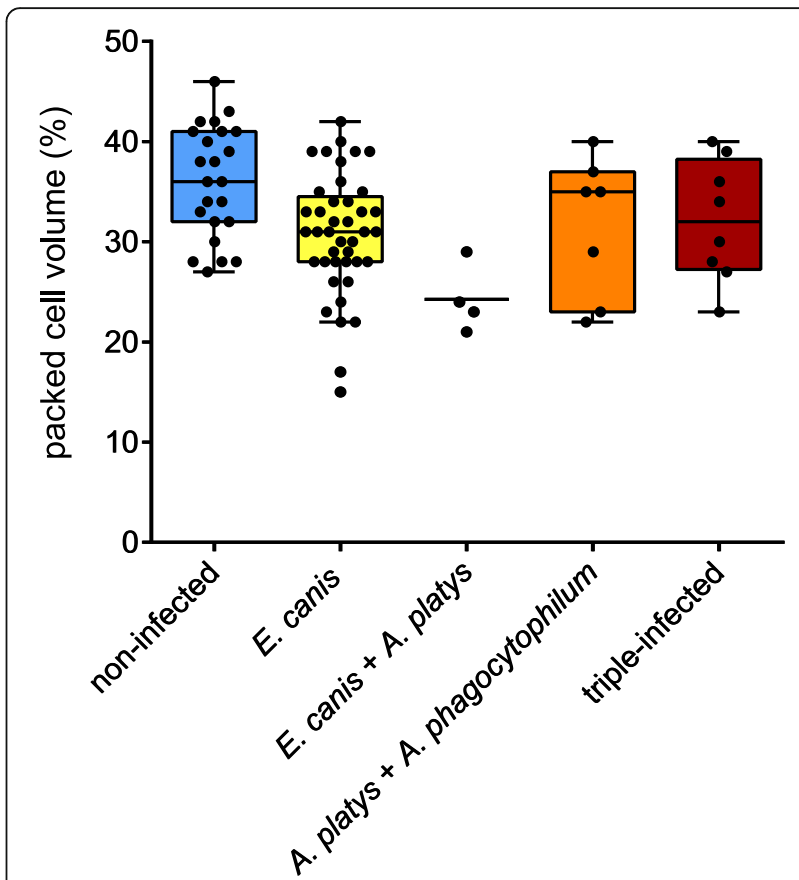

Fig. 2 Packed cell volume of non-infected, mono-infected and co-infected dogs in the subset of animals tested by PCR for current infections (defined as DNA detection) with Ehrlichia canis and Anaplasma spp. $(n=85)$. Since only one dog each was monoinfected with A. phagocytophilum and co-infected with E. canis and A. phagocytophilum, respectively, these were not plotted. No monoinfections with A. platys were found in this data subset. Ends of the boxes define the 25th and 75th percentiles, with a line at the median and whiskers extending to 1.5 the interquartile range or up to the maximum/minimum value

dogs in the subset of 85 animals which were tested by PCR for current infections with all three pathogens. In the linear mixed model, only current $E$. canis infection showed a statistically significant negative impact on PCV, while no significant effect of current $A$. platys or A. phagocytophilum infection on PCV was found (LMM, Table 4).

Twelve of 19 dogs for which anorexia was reported were PCR-positive for $E$. canis, with one individual also carrying current $A$. platys and $A$. phagocytophilum infections. However, for neither pathogen there was a significant difference in the occurrence of anorexia among infected and non-infected dogs (Fisher's exact test, $P=0.1037, P=1$ and $P=1$, respectively).

\section{Discussion}

Dogs may be affected by several vector-borne diseases in the tropics, including important zoonoses. Here, detected

Table 3 Single and multiple infections among the 85 Nicaraguan dogs tested for Anaplasma and Ehrlichia DNA by PCR

\begin{tabular}{|c|c|c|c|c|c|c|c|}
\hline \multirow{2}{*}{$\begin{array}{l}\text { No. of } \\
\text { animals }\end{array}$} & \multicolumn{3}{|c|}{ Single infection } & \multicolumn{4}{|c|}{ Multiple infection } \\
\hline & Apl & Aph & Ec & Apl + Aph & $A p l+E c$ & $A p h+E c$ & $A p l+A p h+E c$ \\
\hline 85 & $0(0.0 \%)$ & $1(1.2 \%)$ & $41(48.2 \%)$ & $7(8.2 \%)$ & $4(4.7 \%)$ & $1(1.2 \%)$ & $8(9.4 \%)$ \\
\hline
\end{tabular}

Abbreviations: Apl, Anaplasma platys; Aph, Anaplasma phagocytophilum; Ec, Ehrlichia canis 
Table 4 Results of LMMs testing the influence of animal sex, age and current infections (as defined by DNA detection) with Ehrlichia canis and Anaplasma platys (Model A) as well as A. phagocytophilum (Model B) on packed cell volume (PVC) of 85 dogs from Nicaragua

\begin{tabular}{llllll}
\hline & Estimate & SE & $d f$ & $t$ & $P$ \\
\hline Model A & & & & & \\
$\quad$ Intercept & 37.35 & 1.89 & 80 & 19.79 & $<0.001$ \\
Sex (ref. male) & 0.15 & 1.31 & 80 & 0.11 & 0.909 \\
Age & -0.33 & 0.26 & 80 & -1.24 & 0.217 \\
E. canis infection & -4.95 & 1.38 & 80 & -3.58 & $<0.001$ \\
A. platys infection & -2.9 & 1.59 & 80 & -1.83 & 0.072 \\
Model B & & & & & \\
Intercept & 36.75 & 2.02 & 80 & 18.19 & $<0.001$ \\
Sex (ref. male) & -0.07 & 1.33 & 80 & -0.05 & 0.961 \\
Age & -0.28 & 0.27 & 80 & -1.03 & 0.306 \\
E. canis infection & -4.95 & 1.43 & 80 & -3.47 & $<0.001$ \\
A. phagocytophilum infection & -0.7 & 1.73 & 80 & -0.4 & 0.688 \\
\hline
\end{tabular}

Full models were significantly different from a null model containing only the random factor "City": likelihood ratio test, $x^{2}=15.28, d f=4, P=0.004$ (Model A); and $X^{2}=11.98, d f=4, P=0.017$ (Model B). Significant $P$-values $(\leq 0.05)$ are printed in bold

Abbreviation: $S E$, standard error

seroprevalence rates among 329 dogs from Nicaragua for Ehrlichia spp. and Anaplasma spp. were considerably higher than those recently reported for Costa Rica (38.2\% and 6.4\%, respectively [9]) and Mexico (30.8\% and 9.9\%, respectively [14]). This could be due to the fact that dogs were only sampled in western parts of Nicaragua, characterized by less rainfall and a higher human population density than the hot and humid Caribbean lowlands in the eastern part of the country. In the abovementioned studies, a higher prevalence of canine vector-borne diseases has also been detected in western compared to central and eastern parts of Costa Rica and Mexico.

Furthermore, Ehrlichia- and Anaplasma-seropositivity were significantly associated with each other. In experimentally infected dogs it has been shown that concurrent Ehrlichia-infection intensifies the humoral immune response to $A$. platys and results in a more persistent $A$. platys infection [29], which may contribute to this phenomenon. Furthermore, both Ehrlichia and A. platys are predominantly transmitted by the brown dog tick Rhipicephalus sanguineus (s.l.), which was the most common tick species parasitizing the dogs in this study [30].

Borrelia burgdorferi (s.l.) antibodies were not detected, which is in line with the very low seroprevalences reported from Mexico and Costa Rica [9, 14], confirming the fact that Central America is not a Lyme borreliosis endemic region. The expected vector for B. burgdoferi (s.l.) are ticks of the genus Ixodes, which seem to be rather rare as parasites of domestic animals in Nicaragua [30,31].
Several risk factors for seropositivity for tested vector-borne diseases were explored. A similar study conducted in Costa Rica reported a higher risk of seropositivity for mongrels compared to dogs of a certain breed as well as a significant effect of sex [9], which could not be confirmed in the current study. However, increasing age was identified as a risk factor for Ehrlichia spp. seropositivity as well as for a positive ELISA result in general, which most likely reflects cumulative pathogen exposure over the animals' lifetime. Similarly, a significantly lower seropositivity rate of dogs under one year of age compared to older dogs was found in Mexico [14]. Furthermore, significant differences between sampling locations were found. High seroprevalences were found in the capital city, Managua, which differed significantly from the lower rates detected in Jinotega, Masaya and Corinto. However, a general pattern concerning the distribution of seropositivity, e.g. differences between coastal and highland locations, cannot yet be established. Furthermore, data on seroprevalences in the eastern parts of the country are still missing, and should be obtained in future studies.

Dirofilaria immitis antigen was detected in six dogs, which were all sampled in the city of Léon, near the Pacific coast. Similarly, D. immitis infections in Costa Rica were almost exclusively detected in districts bordering the Pacific coast $[9,11]$. Higher D. immitis prevalence in coastal regions has also been observed in Mexico [32]. Additionally, microfilariae in two dogs were identified as A. reconditum. In neighbouring Costa Rica, A. reconditum infections have been detected in $11.6 \%$ of tested dogs, while $15 \%$ of dogs showed $D$. immitis infections [11]. In contrast to mosquito-borne dirofilariosis, $A$. reconditum is mainly transmitted by fleas and possibly also by lice as intermediate hosts [33]. Here, approximately $20 \%$ of dogs showed flea infestation at the time of examination. Although $A$. reconditum is less pathogenic than $D$. immitis, it is important to acknowledge the presence of this parasite, as it is a differential diagnosis for D. immitis if microfilariae are observed in blood samples.

Almost $60 \%$ of the Ehrlichia-seropositive dogs were currently infected (as defined as DNA detection by PCR in blood samples) with $E$. canis, i.e. at least $36.7 \%$ of all 329 dogs. In addition to E. canis, E. ewingii and E. chaffeensis also possess high zoonotic potential and antibodies against these Ehrlichia spp. may be detected by the used commercial rapid ELISA. However, we did not test for the presence of E. ewingii or E. chaffeensis by PCR here, as these pathogens have not been detected in ticks or domestic animals in Central America so far [10, 34, 35]. However, E. chaffeensis DNA was isolated from human patients in neighboring Costa Rica [36]. The principal vector of $E$. ewingii and $E$. chaffeensis, Amblyomma americanum, has not been reported to 
occur in Central America [37-39]. Nevertheless, it cannot be entirely excluded that E. ewingii and E. chaffeensis are present in Nicaragua; this should be considered for future studies as well.

Regarding Anaplasma spp., at least $6.6 \%$ of all dogs in the present study were currently infected. Both $A$. platys $(n=20)$, the causative agent of canine cyclic thrombocytopenia, and A. phagocytophilum ( $n=17)$, which causes granulocytic anaplasmosis, were detected. In the majority of cases $(n=15)$, both species were present as co-infections. This result was somewhat surprising. As mentioned above, ixodid ticks, which are known to transmit $A$. phagocytophilum, are rather rare in Central America. Previously, only $A$. platys was reported to infect dogs in Nicaragua [15] and Costa Rica [10]; however, A. phagocytophilum has been found at low prevalence in Rhipicephalus ticks collected from dogs in Costa Rica [35]. It remains to be proven whether or not ticks other than Ixodes spp. may be implicated in the transmission of A. phagocytophilum. Nevertheless, the presence of A. phagocytophilum in Central America is especially important regarding the zoonotic potential of these pathogens. Anaplasma phagocytophilum frequently causes human granulocytic anaplasmosis, while the zoonotic potential of $A$. platys is considered to be low [4].

It cannot be excluded that there were further currently infected dogs amongst the seronegative animals, as antibody titres may not be detectable during the first 16 to 35 days post-infection [29]. However, seronegative animals were not tested by PCR. Therefore, we included only animals tested for current infections with E. canis and both Anaplasma species when assessing the impact of infections on PCV. In the statistical model, only $E$. canis infection had a significant negative impact on PCV. Likewise, Gaunt et al. [29] detected a significantly lower PCV in E. canis-infected dogs, but not in A. platys-infected dogs, compared to a control group. However, they reported that co-infection with both pathogens resulted in more severe anaemia than E. canis infection alone [29]. Here, only four individuals were co-infected with $E$. canis and A. platys, showing on average lower PCV values than those single-infected with $E$. canis. However, this phenomenon was not observed in the group of animals infected with all three pathogens, possibly because animals within this group were in different stages of infection. In general, co-infections may alter and/or exacerbate the clinical presentation of disease [3]; however, infections may also often be asymptomatic [4]. Here, apart from pale mucous membranes, clinical symptoms potentially related to ehrlichiosis or anaplasmosis were only rarely observed, and anorexia, which was frequently reported, was not associated with infection status.

\section{Conclusions}

This study provides the first large-scale assessment of canine vector-borne diseases in Nicaragua. Similar to other Central American countries, a high prevalence of $E$. canis was detected, while $D$. immitis infections were rare and B. burgdorferi (s.l.) infections were not detected. Anaplasma phagocytophilum infections were observed almost as frequently as $A$. platys infections. Thus, dogs may constitute a reservoir for $A$. phagocytophilum in Nicaragua, which should not be neglected in the light of the zoonotic potential of this pathogen. Veterinarians and public health officials in Nicaragua should recommend the use of repellents or acaricides to protect dogs from vector-borne diseases, thus reducing the reservoir for human infection as well as the dog owners' exposure to the vectors.

\section{Acknowledgements}

The authors wish to thank Ursula Küttler for excellent technical assistance.

\section{Funding}

This project was partially funded by IDEXX Laboratories. Study data interpretation is completely independent from the company's opinion and there is no conflict with commercial interests. VMM received funding from the German Academic Exchange Service (DAAD) for a research stay in Germany.

\section{Availability of data and materials}

The datasets supporting the conclusions of this article are included within the article.

\section{Authors' contributions}

VMM collected the blood samples, VMM and SS performed laboratory analyses. CS and VMM designed and coordinated the study. AS performed the statistical analyses and drafted the manuscript. All authors participated in data analysis and interpretation. All authors read and approved the final manuscript.

Ethics approval and consent to participate

Not applicable.

\section{Consent for publication}

Not applicable.

\section{Competing interests}

The authors declare that they have no competing interests.

\section{Publisher's Note}

Springer Nature remains neutral with regard to jurisdictional claims in published maps and institutional affiliations.

\section{Author details}

${ }^{1}$ Institute for Parasitology, Centre for Infection Medicine, University of Veterinary Medicine Hannover, Buenteweg 17, 30559 Hannover, Germany. ${ }^{2}$ Laboratorio de Parasitología, Escuela de Medicina Veterinaria, Universidad Nacional, Campus Benjamín Núñez, Heredia, Costa Rica. ${ }^{3}$ IDEXX Laboratories, Moerikestr. 28/3, 71636 Ludwigsburg, Germany.

Received: 21 August 2018 Accepted: 25 October 2018

Published online: 12 November 2018

\section{References}

1. Harrus S, Baneth G. Drivers for the emergence and re-emergence of vectorborne protozoal and bacterial diseases. Int J Parasitol. 2005;35:1309-18.

2. Otranto D, Dantas-Torres F, Breitschwerdt EB. Managing canine vector-borne diseases of zoonotic concern: part two. Trends Parasitol. 2009;25:228-35. 
3. De Tommasi AS, Otranto D, Dantas-Torres F, Capelli G, Breitschwerdt EB, de Caprariis D. Are vector-borne pathogen co-infections complicating the clinical presentation in dogs? Parasit Vectors. 2013;6:97.

4. Otranto D, Dantas-Torres F, Breitschwerdt EB. Managing canine vector-borne diseases of zoonotic concern: part one. Trends Parasitol. 2009;25:157-63.

5. Day MJ. One health: the importance of companion animal vector-borne diseases. Parasit Vectors. 2011:4:49.

6. Little SE, Heise SR, Blagburn BL, Callister SM, Mead PS. Lyme borreliosis in dogs and humans in the USA. Trends Parasitol. 2010;26:213-8.

7. Duncan AW, Correa MT, Levine JF, Breitschwerdt EB. The dog as a sentinel for human infection: prevalence of Borrelia burgdorferi C6 antibodies in dogs from southeastern and mid-Atlantic states. Vector Borne Zoonotic Dis. 2004; 4:221-9.

8. Moreira-Soto A, Carranza MV, Taylor L, Calderón-Arguedas O, Hun L, Troyo A. Exposure of dogs to spotted fever group rickettsiae in urban sites associated with human rickettsioses in Costa Rica. Ticks Tick Borne Dis. 2016; 7:748-53.

9. Montenegro VM, Bonilla MC, Kaminsky D, Romero-Zúñiga JJ, Siebert S, Krämer F. Serological detection of antibodies to Anaplasma spp., Borrelia burgdorferi sensu lato and Ehrlichia canis and of Dirofilaria immitis antigen in dogs from Costa Rica. Vet Parasitol. 2017;236:97-107.

10. Rojas A, Rojas D, Montenegro V, Gutiérrez R, Yasur-Landau D, Baneth G. Vector-borne pathogens in dogs from Costa Rica: first molecular description of Babesia vogeli and Hepatozoon canis infections with a high prevalence of monocytic ehrlichiosis and the manifestations of co-infection. Vet Parasitol. 2014;199:121-8

11. Rojas A, Rojas D, Montenegro VM, Baneth G. Detection of Dirofilaria immitis and other arthropod-borne filarioids by an HRM real-time GPCR, bloodconcentrating techniques and a serological assay in dogs from Costa Rica. Parasit Vectors. 2015;8:170

12. Santamaria A, Calzada JE, Saldaña A, Yabsley MJ, Gottdenker NL. Molecular diagnosis and species identification of Ehrlichia and Anaplasma infections in dogs from Panama, Central America. Vector Borne Zoonotic Dis. 2014;14: 368-70.

13. Bermúdez CS, Zaldivar AY, Spolidorio MG, Moraes-Filho J, Miranda RJ, Caballero $\mathrm{CM}$, et al. Rickettsial infection in domestic mammals and their ectoparasites in El Valle de Anton, Cocle, Panama. Vet Parasitol. 2011;177:134-8.

14. Movilla R, García C, Siebert S, Roura X. Countrywide serological evaluation of canine prevalence for Anaplasma spp., Borrelia burgdorferi (sensu lato), Dirofilaria immitis and Ehrlichia canis in Mexico. Parasit Vectors. 2016;9:421.

15. Wei L, Kelly P, Ackerson K, Zhang J, El-Mahallawy HS, Kaltenboeck B, et al. First report of Babesia gibsoni in Central America and survey for vectorborne infections in dogs from Nicaragua. Parasit Vectors. 2014;7:126.

16. Stillman BA, Monn M, Liu J, Thatcher B, Foster P, Andrews B, et al. Performance of a commercially available in-clinic ELISA for detection of antibodies against Anaplasma phagocytophilum, Anaplasma platys, Borrelia burgdorferi, Ehrlichia canis, and Ehrlichia ewingii and Dirofilaria immitis antigen in dogs. J Am Vet Med Assoc. 2014;245:80-6.

17. Chandrashekar R, Mainville CA, Beall MJ, O'Connor T, Eberts MD, Alleman $A R$, et al. Performance of a commercially available in-clinic ELISA for the detection of antibodies against Anaplasma phagocytophilum, Ehrlichia canis, and Borrelia burgdorferi and Dirofilaria immitis antigen in dogs. Am J Vet Res. 2010:71:1443-50.

18. O'Connor TP, Hanscom JL, Hegarty BC, Groat RG, Breitschwerdt EB. Comparison of an indirect immunofluorescence assay, western blot analysis, and a commercially available ELISA for detection of Ehrlichia canis antibodies in canine sera. Am J Vet Res. 2006;67:206-10.

19. Mylonakis ME, Papadopoulos E, Koutinas AF, Paitaki C, Leontides L. Comparative methodology for the detection and differentiation of circulating microfilariae of Dirofilaria immitis in the dog. J Helminthol. 2004;78:137-40.

20. Massung RF, Slater K, Owens JH, Nicholson WL, Mather TN, Solberg VB, et al. Nested PCR assay for detection of granulocytic ehrlichiae. J Clin Microbiol. 1998:36:1090-5

21. Martin AR, Brown GK, Hugh Dunstan R, Roberts TK. Anaplasma platys: an improved PCR for its detection in dogs. Exp Parasitol. 2005;109:176-80.

22. Murphy GL, Ewing SA, Whitworth LC, Fox JC, Kocan AA. A molecular and serologic survey of Ehrlichia canis, E. chaffeensis, and E. ewingii in dogs and ticks from Oklahoma. Vet Parasitol. 1998;79:325-39.

23. Dawson JE, Stallknecht DE, Howerth EW, Warner C, Biggie K, Davidson WR, et al. Susceptibility of white-tailed deer (Odocoileus virginianus) to infection with Ehrlichia chaffeensis, the etiologic agent of human ehrlichiosis. I Clin Microbiol. 1994;32:2725-8.

24. Newton LA, Chilton NB, Beveridge I, Hoste H, Nansen P, Gasser RB. Genetic markers for strongylid nematodes of livestock defined by PCR-based restriction analysis of spacer rDNA. Acta Trop. 1998;69:1-15.

25. R Core Team. R Foundation for Statistical Computing, Vienna: Austria; 2016. R: A language and environment for statistical computing. http://www.R-project.org/.

26. Hothorn T, Bretz F, Westfall P. Simultaneous inference in general parametric models. Biom J. 2008:50:346-63.

27. Bates $D$, Mächler M, Bolker B, Walker S. Fitting linear mixed-effects models using Ime4. J Stat Softw. 2015;67:1.

28. Latimer KS, editor. Duncan and Prasse's Veterinary Laboratory Medicine: Clinical Pathology. 5th ed. Ames: IA: Wiley-Blackwell; 2011.

29. Gaunt S, Beall M, Stillman B, Lorentzen L, Diniz P, Chandrashekar R, et al. Experimental infection and co-infection of dogs with Anaplasma platys and Ehrlichia canis: hematologic, serologic and molecular findings. Parasit Vectors. 2010;3:33.

30. Springer A, Montenegro VM, Schicht S, Wölfel S, Schaper SR, ChitimiaDobler L, Siebert S, Strube C. Detection of Rickettsia monacensis and Rickettsia amblyommatis in ticks collected from dogs in Costa Rica and Nicaragua. Ticks Tick Borne Dis. 2018;9:1565-72.

31. Bermúdez CSE, Mejía BL, Hernández L, Apanaskevich DA. First records of Ixodes boliviensis Neumann, 1904 and Dermacentor dissimilis Cooley, 1947 (Ixodida: Ixodidae) as parasites of domestic mammals in Nicaragua. Syst Appl Acarol. 2015;20:462-4.

32. Labarthe N, Guerrero J. Epidemiology of heartworm: what is happening in South America and Mexico? Vet Parasitol. 2005;133:149-56.

33. Pennington NE, Phelps CA. Canine filariasis on Okinawa, Ryukyu Islands. J Med Entomol. 1969;6:59-67.

34. Romero LE, Meneses Al, Salazar L, Jiménez M, Romero JJ, Aguiar DM, et al. First isolation and molecular characterization of Ehrlichia canis in Costa Rica, Central America. Res Vet Sci. 2011;91:95-7.

35. Campos-Calderón L, Ábrego-Sánchez L, Solórzano-Morales A, Alberti A, Tore G, Zobba R, et al. Molecular detection and identification of Rickettsiales pathogens in dog ticks from Costa Rica. Ticks Tick Borne Dis. 2016;7:1198-202.

36. Norman R, Daniela C, Priscilla M. Molecular detection of Ehrlichia chaffeensis in humans, Costa Rica. Emerg Infect Dis. 2015;21:532.

37. Bermúdez CSE, Castro A, Esser H, Liefting Y, García G, Miranda RJ. Ticks (Ixodida) on humans from central Panama, Panama (2010-2011). Exp Appl Acarol. 2012;58:81-8.

38. Esser HJ, Herre EA, Blüthgen N, Loaiza JR, Bermúdez SE, Jansen PA. Host specificity in a diverse Neotropical tick community: an assessment using quantitative network analysis and host phylogeny. Parasit Vectors. 2016;9:1-14.

39. Troyo A, Calderón-Arguedas Ó, Alvarado G, Vargas-Castro LE, Avendaño A. Ectoparasites of dogs in home environments on the Caribbean slope of Costa Rica. Rev Bras Parasitol Vet. 2012;21:179-83.

Ready to submit your research? Choose BMC and benefit from:

- fast, convenient online submission

- thorough peer review by experienced researchers in your field

- rapid publication on acceptance

- support for research data, including large and complex data types

- gold Open Access which fosters wider collaboration and increased citations

- maximum visibility for your research: over $100 \mathrm{M}$ website views per year

At $\mathrm{BMC}$, research is always in progress.

Learn more biomedcentral.com/submissions 